\title{
Evaluasi Pendidikan Agama Islam di Madrasah Tsanawiyah Ibnul Qayyim Putri Yogyakarta
}

\author{
SYAHRI RAMADHAN \\ Konsultan di Leesan Edutrac Indonesia (Lembaga pendidikan, training, dan konsultan dan Dosen Luar \\ Biasa Fakultas Psikologi Universitas Islam Riau, E-mail: ramadhan.pdg@gmail.com
}

\begin{abstract}
Abstrak: Penelitian ini bertujuan untuk; (1) menemukan bentuk-bentuk prinsipprinsip belajar Utsman Najati dalam Pendidikan Agama Islam di MTs Ibnul Qoyyim Putri Yogyakarta; (2) mendeskripsikan faktor-faktor yang mempengaruhi prinsip-prinsip belajar Utsman Najati dalam Pendidikan Agama Islam di MTs Ibnul Qoyyim Putri Yogyakarta; (3) menjelaskan cara yang tepat untuk mengimplementasikan prinsip-prinsip belajar Utsman Najati di MTs Ibnul Qoyyim Yogyakarta.Jenis Penelitian yang digunakan adalah penelitian kualitatif dengan model normatif-evaluatif. Adapun lokasi penelitian adalah di MTs Ibnul Qoyyim Putri Yogyakarta. Teknik pengumpulan data menggunakan wawancara mendalam, observasi, dan dokumentasi. Teknik analisis data melalui tahapan reduksi data, penyajian data, dan verifikasi. Hasil penelitian ini menunjukkan; (1) implementasi prinsip-prinsip belajar Utsman Najati dalam bentuk motivasi, pengulangan belajar, partisipasi aktif, perhatian, pembagian belajar, dan perubahan perilaku secara bertahap ditemukan di MTs Ibnul Qoyyim Putri Yogyakarta. (2) faktor yang mempengaruhi; (a) faktor pendukung, yaitu integrasi program kepondokan dengan madrasah, keseragaman gender, ketersedian sarana dan prasarana memadai, aturan yang jelas, keteladanan yang ditampilkan guru, dan kemampuan guru menggunakan berbagai macam metode pembelajaran; (b) faktor penghambat, yaitu kesiapan guru dalam merancang Rencana Program Pembelajaran (RPP),kegiatan madrasah dan kepondokan terlalu padat, kemampuan murid beragam, buku referensi belum lengkap, alat peraga pembelajaran belum lengkap, kemampuan guru dalam mengajar belum merata, indisipliner, dan ada pihak-pihak yang belum terampil memberikan keteladanan. (3) Cara yang tepat untuk mengimplementasikan prinsip-prinsip belajar Utsman Najati dalam pembelajaran PAI adalah: (a) merencanakan kurikulum pembelajaran mencakup ranah kognitif, afektif dan psikomotorik kedalam Rencana Program Pembelajaran (RPP) dan aturan-aturan keseharian di madrasah dan pondok yang aplikatif, seperti Standard Operating Procedure (SOP), (b) memadukan antara kurikulum PAI madrasah dengan kurikulum kepondokan, (c) melaksanakan dan mengawasi kurikulum dengan pengawasan berjenjang, (d) mengevaluasi pelaksanaan kurikulum pembelajaran PAI secara berkelanjutan dalam jangka waktu tertentu, (e) merekonstruksi kurikulum pembelajaran PAI dengan mengacu kepada hasil evaluasi kurikulum.
\end{abstract}

Kata Kunci : Prinsip-prinsip Belajar, Pendidikan Agama Islam.

\section{PENDAHULUAN}

Salah satu kunci keberhasilan dalam pendidikan adalah proses belajar dan mengajar. Efektivitas dalam kegiatan belajar dan mengajar akan tercapai bila menggunakan prinsipprinsip belajar yang ada di dalam alQur'an. Berasaskan manusia sebagai 
makhluk ciptaan Allah Swt., sehingga hanya Allah Swt., satu-satunya yang tahu segala rahasia tentang manusia. Baharuddinmengatakan bahwa alQur'an seharusnya menempati posisi sentral dalam studi pendidikan Islam, al-Qur'an merupakan sumber motivasi dan inspirasi bagi setiap muslim dalam berpikir, bertindak dan berkreasi, selama al-Qur'an belum diposisikan sebagai penunjuk dan pengayom dalam mencipta atau mengembangkan intelektual dan supra intelektual (qalb) berarti manusia masih jauh dari pemahaman konsep-konsep pendidikan yang sejalan dengan akal dan pikiran manusia (Baharuddin, 2013: 131-132).

Selama ini pendidikan Islam belum menempatkan al-Qur'an pada posisi sentral. Bisa dibuktikan dengan banyaknya persoalan di dalam pendidikan Islam, misalnya kasus bullying yang terjadi di sebuah Sekolah Dasar di Bukittinggi, Sumatera Barat. Lebih ironi lagi, kekerasan tersebut terjadi ketika pelajaran agama Islam. Beberapa waktu yang lalu, kita dikejutkan juga oleh video di youtube yang mempertontonkan beberapa siswa Sekolah Menengah Atas (SMA) mempermainkan gerakan dan bacaan salat ala tarian Harlem Shake. Bahkan hasil penelitian Komisi Perlindungan Anak (KPA) mengungkap fakta yang sangat memprihatinkan tentang degradasi moral remaja di usia sekolah yang banyak melakukan pergaulan bebas dalam survei yang dilakukan pada remaja di 12 kota besar di seluruh Indonesia (Latifah, 2012: 12).

Ada beberapa hal penyebab permasalahan dalam pendidikan Islam, yaitu ; (a) pengaruh dominasi psikologi Barat dalam pendidikan Islam. Sebab kajian tentang psikologi di kalangan ilmuwan muslim baru dilakukan sejak abad ke-20 (Jalaluddin, 2012: 45). Padahal psikologi merupakan ruh pendidikan, tanpa psikologi mustahil pendidikan akan berjalan dengan baik. Psikologi merupakan ilmu yang mempelajari tentang keadaan jiwa manusia. Maka pendidikan tanpa psikologi berarti mendidik manusia seperti robot, (b) merebaknya paham sekuler dikalangan ilmuwan muslim yang cenderung mengabaikan ajaran Islam sebagai bagian dari pengetahuan (Hasan, 2012: 2), (c) fanatisme ilmuwan muslim kontemporer sangat kuat terhadap ilmu yang dikembangkan Barat. Padahal pembagian ilmu yang dikembangkan di Barat meletakkan agama ke dalam ilmu humaniora yang mereduksi peran wahyu dalam bidang keilmuan. Sedangkan ilmuwan muslim seharusnya memposisikan agama sebagai al-'ulum al-naqliyah (al-diniyah) atau revealed knowledge, yang berarti wahyu di dalam Islam mengandung nilai-nilai pengetahuan yang pasti dan menjadi sumber utama dalam membangun pengetahuan (Assegaf, 2012: 1). (d) perbedaan asal dan orientasi, sebab secara fisik menurut konsep Barat tentang manusia adalah bebas nilai, sedangkan dalam konsep Islam manusia adalah makhluk ciptaan Allah Swt. yang memiliki tanggung jawab personal kepada Allah Swt., sehingga manusia terikat dengan nilainilai asal penciptaan-Nya(Jalaluddin, 2012: 47). Nilai-nilai asal penciptaan manusia itu adalah fitrah manusia sebagai hamba dan bertauhid kepada Allah Swt. sebagaimana termaktub di dalam QS ar-Rum [30] ayat 30.

Sebenarnya tidak semua konsep psikologi yang berasal dari Barat itu buruk dan berseberangan dengan konsep Islam, ada sisi-sisi positif yang bisa diambil dan diadopsi oleh para psikolog muslim untuk membangun psikologi Islam. Sebab pada tataran teknis, konsep psikologi yang dikemukakan oleh Barat lebih aplikatif dibandingkan konsep psikologi Islam yang berkembang saat ini. Maka 
psikologi Islam Menurut Abd. Rachman Assegaf hanya perlu menjalankan prinsip al-muhafazhah 'ala qadim al shalih wal akhdzu bi al-jadid al-ashlah, yaitu tetap menjaga (memakai) apa-apa yang baik dari yang sudah ada dan mengadopsi yang baik-baik pula dari yang baru. Sehingga psikologi Islam lebih bersifat netral, tidak ketinggalan zaman karena eksklusif dan tidak kehilangan jati diri karena terlalu terbuka (inklusif) (Asswgaf, 2004: 17). Prinsip ini akan menjaga para psikolog muslim dari sifat isyraf (berlebihlebihan) atau taklid terhadap psikologi Barat. Sebab, sifat isyraf inilah yang kemudian merusak nilai-nilai ilahiah dalam psikologi Islam.

Untuk itu, konsep-konsep psikologi dalam pendidikan Islam di dalam al-Qur'an perlu dikaji kembali agar sejalan dengan fitrah manusia. Maka, penelitian ini akan membahas prinsip-prinsip psikologis dalam belajar di dalam al-Qur'an yang dikemukakan oleh Utsman Najati dalam pembelajaran Pendidikan Agama Islam (PAI). Sebab PAI merupakan gerbang utama dalam internalisasi nilai-nilai agama Islam kepada generasi muslim. Selanjutnya, bila internalisasi nilai itu baik maka baiklah generasi muslim, begitu juga sebaliknya.

Utsman Najati mengatakan bahwa proses belajar akan berjalan dengan baik bila menjalankan prinsip-prinsip tertentu. Kadang kala proses belajar terhambat, tetapi kadang kala juga bisa lancar, hal itu disebabkan oleh tidak dipakainya prinsip-prinsip belajar dengan baik (Najati, 2005: 268). Adapun mengenai prinsip-prinsip psikologis dalam belajar Utsman Najati menyarikannya dari konsep-konsep belajar menurut al-Qur'an. Prinsipprinsip psikologis dalam belajar menurut Utsman Najati tersebut adalah;

(a) Motivasi, (b) Pengulangan belajar,

(c) Perhatian, (d) Partisipasi aktif, (e)
Pembagian belajar, dan (f) Perubahan perilaku secara bertahap (Najati, 2001: 169-187).Prinsip-prinsip belajar yang dikemukakan oleh Utsman Najati merupakan ajaran al-Qur'an tentang bagaimana seharusnya kegiatan belajar dan mengajar berjalan dengan baik dan mampu membawa kepada tujuan belajar yang sudah di tetapkan.

Berdasarkan latar belakang permasalahan di atas, dapat diidentifikasikan permasalahan penelitian ini adalah: (a) Pengaruh ilmu pengetahuan yang berasal dari Barat yang berbeda substansi asal, substansi, dan orientasinya dengan ajaran Islam sangat kuat pengaruhnya dalam sistem pendidikan di sekolah-sekolah Islam; dan (b) Prinsip-prinsip belajar di dalam al-Qur'an yang disampaikan Utsman Najati sangat penting sekali dalam PAI, tapi ada asumsi bahwa prinsip-prinsip belajar tersebut justru tidak terlaksana dengan baik di sekolah-sekolah Islam. Sehingga menimbulkan berbagai permasalahan dalam pendidikan Islam.

Berdasarkan identifikasi masalah di atas, maka rumusan masalah dalam penelitian ini adalah: (1) Apakah bentuk prinsip-prinsip belajarUtsman Najati yang ada dalam PAI di Madrasah Tsanawiyah Ibnul Qoyyim Putri Yogyakarta; (2) Apa sajakah faktorfaktor yang memengaruhi prinsipprinsip Utsman Najatidalam PAI di Madrasah Tsanawiyah Ibnul Qoyyim Putri Yogyakarta; dan (3) Bagaimanakah cara yang tepat untuk mengimplementasikan prinsip-prinsip belajar Utsman Najati dalam PAI di Madrasah Tsanawiyah Ibnul Qoyyim Putri Yogyakarta.

\section{METODE}

Penelitian ini menggunakan metode penelitian kualitatif dengan model normatif-evaluatif. Lokasi penelitian di Madrasah Tsanawiyah 
Ibnul Qoyyim Putri Yogyakarta.Data dikumpulkan melalui wawancara mendalam, observasi, dan dokumentasi. Kemudian diolah dengan tiga tahapan, yaitu mereduksi data (data reduction), menyajikan data (data display), dan menarik kesimpulan (verification).

\section{KONSEP TEORI}

\section{Pendidikan Agama Islam}

Pengertian PAI yang dimaksud dalam penelitian ini adalah mengacu kepada pendapat Abdul Majid, Zakiyah Daradjat, dan Tayar Yusuf, yaitu pertama, menyangkut pendidikan secara sadar dan terencana (perencanaan). Kedua, proses transfer pengetahuan (pelaksanaan). Ketiga, sumber pendidikan yang berasal dari al-Qur'an dan al-Hadits (Materi). Keempat bertujuan menghasilkan murid yang beriman, bertakwa, berakhlak mulia, menghayati dan mengamalkan ajaran Islam, serta kemampuan untuk hidup berdampingan dengan penganut agama lain dalam konteks kehidupan berbangsa dan bernegara yang berlandaskan syariat Islam (tujuan) (Majid, 2012: 11-12).

\section{Hakikat Belajar dan Faktor yang Mempengaruhi Belajar}

Belajar sudah menjadi kata yang sangat familiar dalam dunia pendidikan, sehingga banyak para ahli pendidikan maupun psikologi yang merumuskan definisi belajar. Namun, dari berbagai definisi yang dikemukakan dapat dirangkum menjadi pokok-pokok pengertian sebagai berikut : (a) Belajar selalu membawa perubahan pada individu baik yang tampak (aktual) maupun tidak tampak (potensial); (b) Perubahan dalam belajar adalah diperolehnya kemampuan baru; (c) Adanya usaha atau proses yang dilalui untuk mendapatkan perubahan itu; (d) Usaha atau proses situ disebut sebagai pengalaman (experience); dan (e) Usaha atau proses belajar bisa terjadi melalui respon individu terhadap lingkunganya dan juga karena adanya pelatihan khusus.

Selanjutnya, belajar dipengaruhi oleh berbagai faktor, misalnya faktor non-sosial, seperti waktu, tempat, cuaca. Ada juga faktor sosial, misalnya suara yang sering kali mengganggu proses belajar. Selain dua faktor tersebut masih ada faktor psikologis, misalnya tingkat kecerdasan (IQ), bakat, minat, dan keadaan emosi. Lalu ada faktor fisiologis, misalnya kondisi sehat, atau sakit (Suryabrata, 2014: 236-237). Maka banyak hal yang mempengaruhi belajar selain yang disebutkan tersebut.

\section{Belajar dalam al-Qur'an}

Belajar menjadi salah satu anjuran bahkan kewajiban bagi setiap umat Islam sebagaimana yang diperintahkan di dalam al-Qur'an. Bahkan wahyu pertama yang diturunkan Allah Swt., di dalam al-Qur'an merupakan perintah untuk belajar. Allah SWT berfirman:
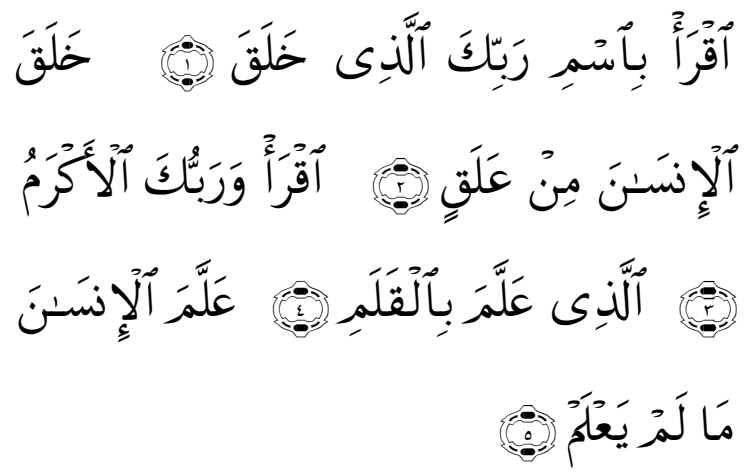

Artinya: "Bacalah dengan (menyebut) nama Tuhanmu Yang menciptakan. Dia telah menciptakan manusia dari segumpal darah. Bacalah, dan Tuhanmulah Yang Maha Pemurah. Yang mengajar (manusia) dengan perantaran 
kalam. Dia mengajar kepada manusia apa yang tidak diketahuinya". (QS. Al-Alaq, 96:1-5).

Di dalam berbagai ayat lain Allah Swt. juga menjelaskan bagaimana Adam as., belajar berbagai nama-nama dan bahasa (lihat : QS. al-Baqarah [2] : 3132). Allah Swt., juga mengatakan bahwa Dialah yang telah mengajarkan alQur'an dan Dia pula yang telah menciptakan manusia (lihat : QS. arRahman [55] : 2-3). Kemudian Allah Swt., juga memberikan contoh bagaimana Adam as., diajarkan memilih dan membuat keputusan (lihat : QS. alBaqarah [2] : 35-37),dan masih banyak lagi penjelasan-penjelasan al-Qur'an tentang belajar yang termaktub di dalam al-Qur'an.

Selain itu, di dalam al-Qur'an juga terdapat gambaran bagaimana manusia itu belajar, sebagaimana yang disimpulkan oleh Utsman Najati dari hasil kajiannya terhadap kandungan alQur'an. Menurutnya ada tiga cara manusia belajar menurut al-Qur'an, yaitu dengan cara meniru (imitation), pengalaman trial dan error, dan berfikir (Najati, 2005: 258). Selanjutnya Utsman Najati juga menyimpulkan berbagai prinsip-prinsip belajar menurut alQur'an yang akan dibahas pada bahasan berikutnya.

\section{Prinsip-prinsip belajar Utsman Najati}

Adapun prinsip-prinsip belajar yang disarikan Utsman Najati dari alQur'an terdiri dari enam prinsip, yaitu motivasi, pengulangan, perhatian, partisipasi aktif, pembagian belajar, dan perubahan perilaku secara bertahap (Najati, 2001: 169-194).

Pertama, Motivasi. Para psikolog modern membedakan antara motif dengan motivasi, dimana motif lebih dimaknai sebagai dorongan, daya gerak, ransangan dan insting. Sedangkan motivasi lebih dimaknai kepada segala sesuatu yang yang menjadi pendorong tingkah laku seseorang atau menuntut seseorang untuk melakukan sesuatu. Maka disini motivasi sebagai pendorong tingkah laku, pemberi rangsang, pengerak, pemberi atau pemuncul motif (Shaleh, 2009: 182-183). Hal ini sesuai dengan apa yang dikatakan Utsman Najati bahwa motivasi adalah kekuatan penggerak yang membangkitkan aktivitas pada makhluk hidup, menimbulkan tingkah laku, serta mengarahkan pada tujuan tertentu.

Lebih lanjut Utsman Najati mengatakan pentingnya motivasi akan menjadikan orang memiliki keinginan yang kuat dalam meraih apa yang dia inginkan atau tujuannya, orang yang mempunyai motivasi yang kuat senantiasa akan mencurahkan ikhtiarnya dengan sekuat tenaga, melakukan cara-cara yang akan menyampaikannya kepada tujuannya, bahkan bisa melakukan berbagai usaha untuk mencapai tujuannya itu (Najati, 2001: 169). Selanjutnya menurut Thorndike dalam hukum belajarnya law of readiness bahwa motivasi untuk bertindak sangat mempengaruhi kepuasan orang dalam melakukan sutu tindakan (Mulyati, 2007: 41-42). Adapun metode-metode motivasi yang digunakan dalam al-Qur'an yang dikemukakan oleh Ustman Najati adalah membangkitkan motivasi melalui targhîb dan tarhîb, cerita, dan memanfaatkan peristiwa penting (Najati, 2001: 169-176).

Kedua, Pengulangan. Utsman Najati mengatakan bahwa pengulangan pemikiran tertentu kepada seseorang akan membuat pemikiran tersebut tertanam kuat di dalam benaknya. Beberapa hasil penelitian para psikolog modern mengungkapkan pentingnya pengulangan dalam proses belajar. 
Perusahan-perusahan industri telah mengetahui pentingnya pengulangan dalam menguatkan opini ke dalam hati seseorang. Perusahan-perusahan tersebut rela mengeluarkan biaya yang sangat besar guna mengulang-ulang promosi dan penanaman opini tertentu kepada para konsumen (Najati, 2001: 176).

Ketiga, Perhatian. Perhatian merupakan bagian penting dalam belajar, menimba pengetahuan, dan memperoleh ilmu. Orang yang tidak menaruh perhatian terhadap pelajaran tidak akan mampu memahami tentang apa yang diajarkan. Maka dari itu, para pengajar maupun pendidik senantiasa berusaha membangkitkan perhatian murid untuk memperhatikan apa yang diajarkan. Cara -cara menggugah perhatian dalam belajar, yaitu: (1) Dengan cerita; (2) Dengan memanfaatkan peristiwa penting; (3) Dengan pengulangan; (4) Dengan memberikan contoh kongkrit yang berkaitan dengan kehidupan nyata (perumpamaan); (5) Memberikan penekanan pada informasi (dengan sumpah); dan (6) Memunculkan informasi baru.

Keempat, Partisipasi aktif. Menurut Utsman Najati mempelajari keterampilan motorik mengharuskan murid melakukan keterampilan tersebut secara sungguh-sungguh serta melatihnya hingga akhir. Latihan motorik bukan hanya berguna untuk mempelajari materi-materi praktis saja, tapi juga bermanfaat untuk pelajaran teoretis, seperti mempelajari akhlak, keutamaan, nilai-nilai, dan etika bergaul bermasyarakat. Kesiapan seseorang untuk belajar secara mandiri akan membantunya untuk mempercepat menuntaskan belajar. Salah satu hasil penelitian membuktikan bahwa seseorang yang membaca huruf-huruf dan kata-kata yang berlawanan lebih cepat hafal dibandingkan yang hanya mendengarkan saja. Padahal mereka melihat dalam waktu yang sama melalui media audio visual (Najati, 2001: 185).

Kelima, Pembagian Belajar.

Penelitian yang dilakukan secara eksperimen oleh para psikolog modern membuktikan tentang pembagian belajar atau latihan ke dalam rentang waktu yang berjauhan diselingi waktu istirahat akan membantu mempercepat belajar dan mamantapkannya dalam memori. Belajar dengan menggunakan metode pembagian ini lebih efektif dibandingkan belajar dengan metode terpusat, yakni metode belajar tuntas dalam rentang waktu yang bersambungan tanpa diselingi waktu istirahat.

Keenam, Perubahan Perilaku Secara Bertahap. Meninggalkan beberapa kebiasaan buruk yang sudah mendarah daging karena sudah dilakukan sekian lamanya memang bukan suatu perkara yang mudah. Sebab, hal itu membutuhkan azam yang kuat, kesungguhan yang besar, dan latihan yang relatif lama. Sehingga tidak banyak orang yang sanggup melakukannya. Maka cara yang efektif untuk meninggalkan perbuatan buruk itu adalah dengan meninggalkannya secara bertahap.

Kaidah-kaidah yang perlu diperhatikan dalam perubahan perilaku secara bertahap. Cara yang diajarkan alqur'an dalam merubah perilaku manusia, yaitu: (1) Menangguhkan perbaikan kebiasaan buruk, sampai iman tertanan kuat kedalam hati manusia; dan (2) Melatih mental kaum muslimin dengan cara membentuk respon yang berlawanan secara bertahap dengan respon yang dituntut untuk dilepaskan, misalnya dalam perintah meninggalkan khamr dan riba.

Bila dicermati prinsip-prinsip belajar Utsman Najati, memiliki kaidah yang sama dengan law of learning yang dikemukakan oleh psikolog Amerika, 
Thorndike. Menurut Thorndike bahwa prinsip-prinsip belajar akan berlangsung pada prinsip-prinsip yang sama baik bagi hewan maupun manusia berdasarkan tiga hukum belajar yang dia kemukakan, yaitu law of readiness, law of exercise, law of effect (Mulyati, 2007: 41-42).

Hukum law of readiness berkaitan dengan tiga permasalahan. Pertama, yaitu orang memiliki keinginan (kesiapan) untuk bertindak, lalu dia melakukannya maka dia puas. Kedua, apabila orang memiliki keingingan untuk bertindak, tapi dia tidak melakukannya, maka dia tidak mendapatan kepuasan. Ketiga, bila orang tidak memiliki keinginan untuk bertindak, tapi dia diharuskan bertindak, maka dia tidak puas. Hukum law of readiness Thorndike ini terdapat juga didalam prinsip-prinsip belajar Utsman Najati yang lebih rinci membicarakan mengenai motivasi dengan cara-cara yang menjadikan murid siap (ready) untuk belajar.

Hukum law of exircise adalah prinsip pengulangan atau latihanlatihan akan memperkuat tindakantindakan dan akan melemah seiringnya sedikitnya latihan atau pengulangan. Hal ini sesuai dengan konsep yang dikemukakan Utsman Najati, bahwa pengulangan akan menjadikan informasi tertanam kuat ke dalam fikiran manusia. Lebih detail Utsman Najati juga mengemukakan metodemetode pengulangan yang variatif, sehingga menghilangkan bias bosan dalam proses belajar.

Hukum law of effect menyatkan bahwa akibat dari suatu perbuatan mempengaruhi orang untuk melakukan perbuatan itu lagi. Apabila akibatnya menyenangkan, maka orang akan cenderung mengulangnya, apabila akibatnya tidak menyenangkan maka orang cenderung meninggalkannya.
Hukum ini sesuai dengan prinsip targhib dan tarhib yang dikemukakan oleh Utsman Najati, bahwa manusia memiliki kecenderungan untuk melakukan hal-hal yang mendatangkan kebahagian dan menghindari hal-hal yang mendatangkan ketidaknyamanan.

Selain tiga hukum primer yang dikemukakan di atas, Thorndike juga mengemukakan lima hukum turnannya (subsider), yaitu law of multiple respons, law of attitude, laf of partial activity, law of response by analogy, dan law of associative shifting (Mulyati, 2007: 41).

Hal yang membedakan antara law of learning Throrndike dengan prinsipprinsip belajar Utsman Najati adalah pada esensi asal dan tujuannya, sebab hukum belajar Thorndike merupakan hasil eksperimen terhadap binatang. Sehingga tidak sampai ke fitrah manusia, yakni pentingnya landasan iman dan tauhid dalam setiap tindakan belajar yang menjadi ruh dari prinsipprinsip belajar Utsman Najati. Hal ini menunjukkan bahwa setiap tindakan yang dilakukan manusia dalam usaha belajar tidak semata-mata karena dorongan hadiah dan kebiasaan. Tapi ada supra power(yaitu iman/tauhid) yang menjadikan manusia mempunyai keinginan dan menjadi bisa untuk belajar.

\section{HASIL DAN PEMBAHASAN \\ Bentuk-bentuk penerapan prinsip- prinsip belajar Utsman Najati dalam pembelajaran PAI di MTs Ibnul Qoyyim Putri Yogyakarta}

Dari data lapangan yang didapatkan, kemudian dianalisis dengan teori prinsip-prinsip belajar Utsman Najati. Maka dapat dikelompokkan bentukbentuk aplikasi prinsip-prinsip belajar Utsman Najati dalam pembelajaran PAI seperti tabel di bawah ini : 
Tabel 1.

Bentuk-bentuk penerapan prinsip-prinsip belajar Utsman Najati yang ditemukan di MTs Ibnul Qoiyyim Putri Yogyakarta

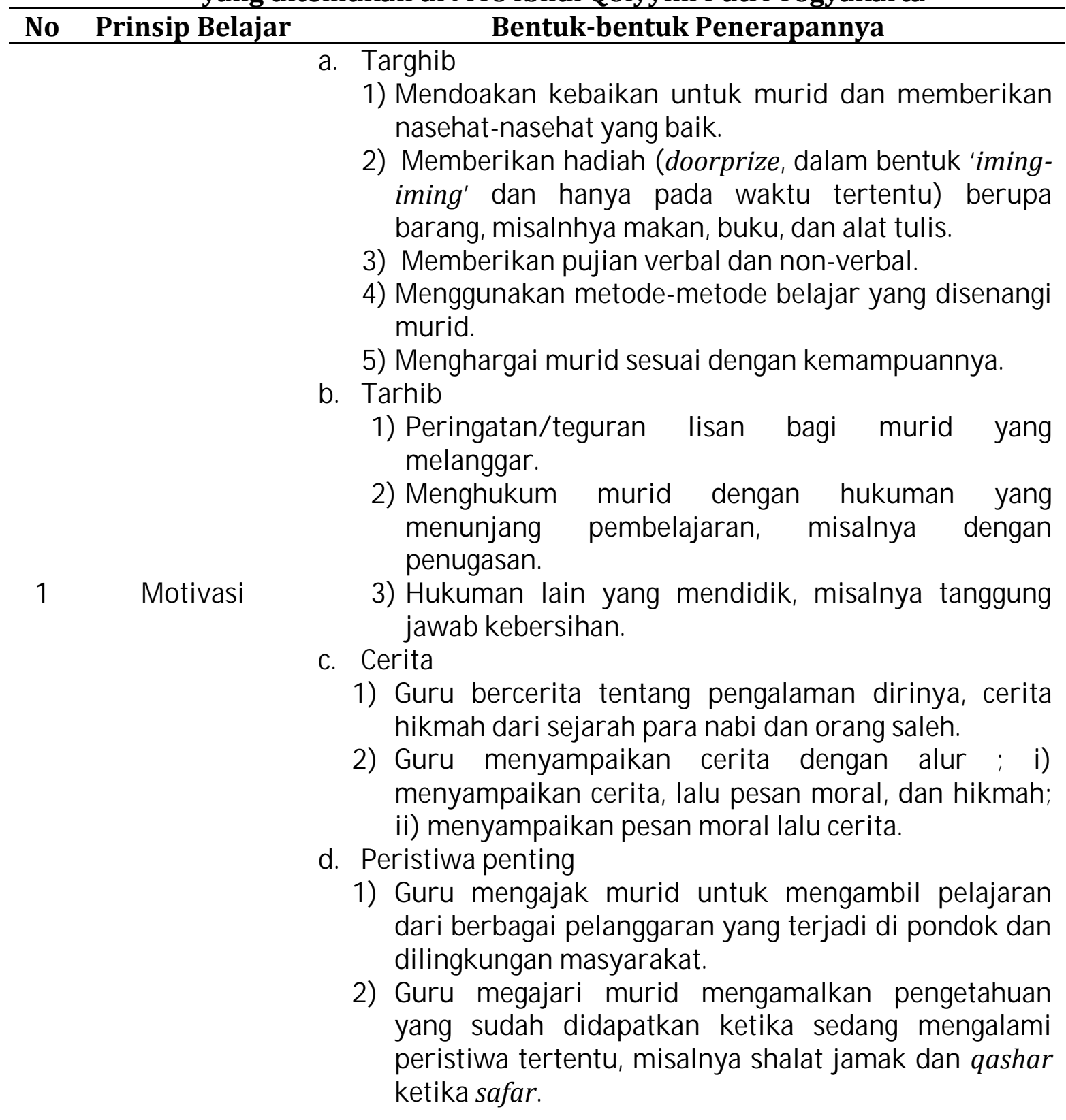

1) Review dan post-test,

2) Ujian komprehensif sebelum Ujian Kenaikan Kelas (UKK) dan Ujian Madrasah (UM) di kelas 3 MTs.

3) Pengulangan hafalan pada materi-materi yang penting dan pokok untuk dikuasai murid.

2 Pengulangan

4) Pengulangan dengan pembiasaan dalam keseharian murid, misalnya pembiasaan berbahasa Arab sehari-hari di saat pelajaran di dalam kelas maupun di lingkungan pondok.

5) Memberikan tugas kepada murid untuk membuat kesimpulan dari pelajaran yang sudah disampaikan sesuai dengan apa yang mereka pahami danmuraja'ah 
pelajaran secara berpasangan.

6) Pengulangan dengan metode yang berbeda, misalnya dari metode ceramah, ke tanya jawab, atau ke metode praktikum.

\begin{tabular}{|c|c|c|}
\hline 3 & Perhatian & $\begin{array}{l}\text { 1) Melibatkan dengan melakukan praktikum, diskusi dan } \\
\text { presentasi kelompok, dan menggunakan media audio- } \\
\text { visual. } \\
\text { 2) Inovasi metode pembelajaran. } \\
\text { 3) Memberikan contoh-contoh untuk penjelasan materi } \\
\text { pelajaran dari kejadian sehari-hari dan cerita-cerita dan } \\
\text { kata hikmah yang bisa menggugah perhatian murid. } \\
\text { 4) Memberikan pertanyaan-pertanyaan lisan tentang } \\
\text { materi yang sudah atau sedang dipelajari. } \\
\text { 5) Menarik perhatian murid dengan mendo'akan kebaikan } \\
\text { bagi murid. }\end{array}$ \\
\hline 4 & Partisipasi aktif & $\begin{array}{l}\text { 1) Praktikum. } \\
\text { 2) Presentasi dan diskusi kelompok. } \\
\text { 3) Sosiodrama. } \\
\text { 4) pengamalan langsung, misalnya dalam ibadah wudhu, } \\
\text { shalat, puasa senin-kamis, dan puasa Daud. }\end{array}$ \\
\hline 5 & $\begin{array}{l}\text { Pembagian } \\
\text { belajar }\end{array}$ & $\begin{array}{l}\text { 1) Mata pelajaran PAI dijadwalkan setiap hari dengan } \\
\text { konsentrasi yang berbeda-beda (Fikih, Qur'an Hadits, } \\
\text { Sejarah Kebudayaan Islam, Bahasa arab, dan Akidah } \\
\text { Akhlak) dengan alokasi jam pelajaran 2-3 jam perminggu } \\
\text { diselingi mata pelajaran lainnya. } \\
\text { 2) Untuk mata pelajaran konsentrasi PAI yang } 3 \text { jam } \\
\text { perminggu disampaikan dalam } 2 \text { kali pertemuan dengan } \\
\text { hari yang berbeda, masing-masing } 2 \text { jam per pertemuan } \\
\text { dan } 1 \text { jam per pertemuan. } \\
\text { 3) Untuk mata pelajaran konsentrasi PAI dengan } 2 \text { kali } \\
\text { pertemuan perminggu disampaikan dalam selang waktu } \\
1 \text { hari. } \\
\text { 4) Ada penambahan waktu pembelajaran diluar kelas } \\
\text { dengan menggabungkan program kepondokan dengan } \\
\text { pembelajaran PAI. }\end{array}$ \\
\hline
\end{tabular}

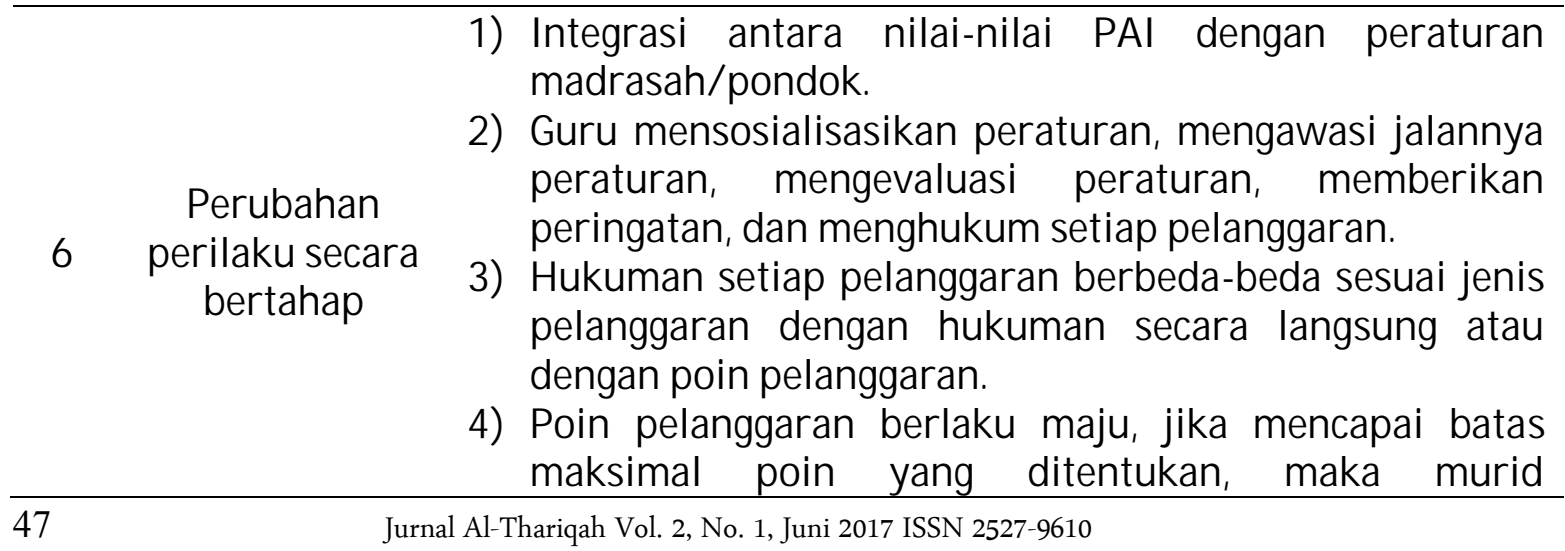


dikembalikan kepada orang tua.

5) Guru memberikan teladan secara langsung kepada murid.

6) Guru menanamkan keyakinan tauhid kepada murid.

7) Mengadakan program pembiasaan dalam keseharian murid, seperti bahasa arab sehari-hari, shalat jama'ah, dhuha, puasa, dan tadarus, dan muraja'ah.

Faktor-faktor yang mempengaruhi prinsip-prinsip belajar Utsman Najati dalam pembelajaran PAI di MTs Ibnul Qoyyim Putri Yogyakarta

Ada dua faktor yang mempengaruhi penerapan prinsipprinsip belajar Utsman Najati di Madrasah Tsanawiyah Ibnul Qoyyim Putri Yogyakarta, yaitu faktor yang mendukung dan faktor yang menghambat.Pertama, faktor-faktor pendukung, di antaranya adalah adanya program kepondokan yang terintegrasi dengan program madrasah, adanya keseragaman gender, ketersedian sarana dan prasarana yang memadai, adanya aturan yang jelas, adanya keteladanan yang ditampilkan guru, dan kemampuan guru dalam menggunakan berbagai macam metode pembelajaran. Kedua, faktor-faktor yang menjadi penghambat, di antaranya adalah program madrasah dan kepondokan yang terlalu padat, kemampuan murid yang sangat beragam, buku referensi untuk guru dan murid belum lengkap, alat peraga pembelajaran belum lengkap, kemampuan guru dalam mengajar belum merata, indisipliner, dan masih ada pihak-pihak yang belum terampil memberikan keteladanan.

\section{Cara yang tepat untuk mengimplementasikan prinsip- prinsip belajar Utsman Najati di MTs Ibnul Qoyyim Putri Yogyakarta}

Hasil penelitian ini menunjukkan bahwa bentuk-bentuk aplikasi prinsipprinsip belajar Utsman Najati ditemukan dalam pembelajaran PAI di MTs Ibnul Qoyyim Putri Yogyakarta.Namun, prinsip-prinsip belajar Utsman Najati belum terimplementasi dengan baik. Apabila diambil kesimpulan dari berbagai faktor yang mempengaruhinya, maka bisa dikelompokkan menjadi tiga faktor. Yaitu; (a) faktorpendidik; persiapan Rencana Program Pembelajaran (RPP) dan keterampilan menampilkan keteladanan, (b) faktor murid;murid ketiduran saat belajar di kelas, perbedaan kemampuan pada murid, dan murid yang kurang memperhatikan pelajaran. (c) faktor sistem;program kepondokan yang terlalu padat dan pengawasan aktivitas murid pada malam hari.

Untuk mengatasi persoalan dalam pembelajaran PAI, maka pihak sekolah atau pondok bisa mempertimbangkan ketiga faktor di atas.Untuk faktor pertama, yaitu guru yang terkendala dengan kesiapan dalam merencanakan kegiatan pembelajaran dan keterampilan menampilkan keteladanan. Pihak sekolah dapat mengadakan berbagai pendidikan dan pelatihan untuk meningkatkan soft skill maupunhard skill guru dalam merancang dan mengaplikasikan kegiatan pembelajaran. Hal ini sangat penting, sebab menurut Thorndike seorang guru harus mampu menciptakan kesiapan belajar pada muridnya (law of readiness). Apabila murid siap untuk belajar, itu artinya murid memiliki motivasi yang cukup untuk belajar, maka kegiatan 
pembelajaran akan menyenangkan dan hasil yang dicapai akan maksimal. Law of readiness bisa direncanakan dengan cara-cara memotivasi murid seperti yang dikemukakan oleh Utsman Najati, dengan targhib dan tarhib, misalnya dengan mengecek kesiapan murid dengan Ice Breaking diawal pelajaran, menanyakan kabar murid, menanyakan pengalaman bahagianya hari ini, membacakan kata-kata hikmah, menyampaikan keutamaan orang yang menuntut ilmu, dan memberikan keteladanan. Kemudian bisa juga dengan bercerita tentang hal yang menarik dan menggugah perhatian siswa, apakah cerita tentang orang saleh, atau kejadian sehari-hari.

Faktor kedua, yaitu persoalan murid dalam belajar, seperti murid ketiduran saat belajar di kelas, perbedaan kemampuan pada murid, dan murid yang kurang memperhatikan pelajaran. Persoalam ini sebetulnya sudah diatasi sebagian dengan law of readiness, selanjutnya guru bisa menggunakan law of exercise, terutama untuk mengatasi kemampuan murid yang beragam. Untuk manambah pemahaman pada murid maka guru bisa menggunakan prinsip pengulangan belajar, membuat regulasi belajar yang variatif diselingi waktu istirahat dan manajemen materi yang terstrutur dengan baik, dan melibatkan murid secara aktif dalam kegiatan pembelajaran, misalnya dengan metode praktikum, sosiodrama, diskusi dan presentasi, studi pustaka, dan outing class (mengunjungi museum, tempat bersejarah, dan lainnya). Menggunakan variasi dalam metode belajar dan inovasi pembelajaran akan menimbulkan dampak menyenangkan dan menarik perhatian murid. Apabila belajar sudah menarik yang menyenangkan, maka murid akan memiliki keinginan yang kuat untuk belajar lagi, sebab menurut hukum law of effect Thorndike, akibat yang baik akan mengarahkan seseorang untuk mengulangi tindakan yang sama, sedangkan akibat yang buruk akan menyebabkan orang meninggalkan tindakan itu.

Faktor ketiga, yaitu sistem. Dapat dilakukan dalam lima cara, yaitu; pertama, merencanakan kurikulum pembelajaran yang mencakup ranah kognitif, afektif dan psikomotorik murid kedalam Rencana Program Pembelajaran (RPP) dan aturan-aturan keseharian di madrasah maupun di pondok yang aplikatif, seperti Standard Operating Procedure (SOP). Kedua, mengintegrasikan antara kurikulum PAI madrasah dengan kurikulum kepondokan. Ketiga, melaksanakan dan mengawasi rencana yang sudah dibuat dengan sistem pengawasan berjenjang. Keempat, mengevaluasi hasil pelaksanaan kurikulum pembelajaran PAI secara berkelanjutan dalam jangka waktu tertentu. Kelima, merekonstruksi kurikulum pembelajaran PAI dengan mengacu kepada hasil evaluasi yang sudah dilakukan.

\section{SIMPULAN}

Dari analisis peneliti, dapat disimpulkan bahwa prinsip-prinsip belajar Utsman Najati ditemukan dalam pembelajaran PAI di MTs Ibnul Qoyyim Putri Yogyakarta. Namun, belum sepenuhnya terimplementasikan dengan baik disebabkan oleh berbagai faktor penghambat pada aspek perencanaan, pelaksanaan, pengawasan, dan evaluasi program madrasah dan kepondokan. Maka disarankan agar prinsip-prinsip belajar Utsman Najati terimplementasi dengan baik, yaitu ; (1) program pemerataan kemampuan guru dalam merencanakan, melaksanakan, dan mengevaluasi proses pembelajaran dengan cara 
memberikan pendidikan dan pelatihan untuk meningkatkan soft skill maupun hard skill guru, misalnya pelatihan membuat administrasi pembelajaran, studi banding, outbound, dan Achivement Motivation Training. (2) menjadwal ulang kegiatan madrasah dan kepondokan untuk mengatasi permasalahan banyaknya murid yang mengantuk pada saat pembelajaran di kelas siang hari, yakni dengan adanya program belajar di sepertiga malam akhir dan qailulah (tidur/istirahat siang) sebelum atau sesudah zuhur.

\section{DAFTAR RUJUKAN}

A.B.PHasan. Psikologi Islam Sebagai Ilmu Pengetahuan : Epistemologi dan Pengembangan di Masa Depan. Jurnal Psikologi. Vol. V, No. 1, Juni 2012.

Assegaf, Abd. Rachman. 2012. Antologi Pendidikan Islam. Yogyakarta: Idea Press.

Assegaf, Abdul Rachman. 2004. Pendidikan Islam dan Tantangan Globalisasi : Buah Pikiran Seputar Filsafat, Politik, Ekonomi, Sosial, dan Budaya. Yogyakarta: Ar-Ruzz.
A.S.A Latifah. Proses Pembelajaran Agama Islam di SMA Plus Assalam Bandung. Jurnal Tarbawi, Vol. 1, No. 1, Tahun 2012.

Baharuddin. 2013. Aktualisasi Psikologi Islami. Yogyakarta: Pustaka Pelajar.

Jalaluddin. 2012. Psikologi Agama : Memahami Perilaku dengan Mengaplikasikan Prinsip-prinsip Psikologi. Jakarta: Rajawali.

Majid, Abdul. 2012. Belajar dan Pembelajaran Pendidikan Agama Islam. Yogyakarta: Rosda Karya.

Mulyati. 2007. Pengantar Psikologi Belajar. Yogyakarta: Quality Publishing.

Najati, Utsman. 2005. Psikologi dalam Al-Qur'an: Terapi Qur'ani dalam Penyembuhan Gangguan Kejiwaan. Pustaka Setia. Bandung.

Najati, Utsman. 2001. Al-Qur'an Wa 'Ilmun Nafs. Beirut: Daarus Syuruuq.

Shaleh, Abdul Rahman. 2009. Psikologi Suatu Pengantar Dalam Perspektif Islam. Jakarta: Kencana.

Suryabrata, Sumadi. 2014. Psikologi Pendidikan. Jakarta: Rajawali Pers. 